\title{
Oculo-peritoneal shunt: draining aqueous humor to the peritoneum
}

\section{Derivação óculo-peritoneal: drenagem do humor aquoso para o peritônio}

Ana Maldonado-Junyent ${ }^{1}$, Arturo Maldonado-Bas ${ }^{2}$, Andrea Gonzalez ${ }^{3}$, Francisco Pueyrredón ${ }^{4}$, María Maldonado-Junyent ${ }^{1}$, Arturo Maldonado-Junyent ${ }^{1}$, Diego Rodriguez ${ }^{3}$, Mariano Bulacio ${ }^{5}$

\begin{abstract}
In 2010, there were estimated to be approximately 60.5 million people with glaucoma. This number is expected to increase to 79.6 million by 2020. In 2010, there were 8.4 million people with bilateral blindness caused by glaucoma, and this number is expected in increase to 11.2 million by 2020 . Filtering implants are special devices that have been developed to reduce intraocular pressure in patients with refractory glaucoma. The success rate of these implants is relatively low, and they continue to fail over time. To avoid failure caused by the formation of scar tissue around the implants, attempts have been made to drain the aqueous humor to various sites, including the venous system, lacrimal sac, sinuses, and conjunctival fornix. Recently, a system to shunt aqueous humor from the anterior chamber to the peritoneum has been developed. The surgical technique involved in this system is a modification of the technique currently used by neurosurgeons for the treatment of hydrocephalus. We present the first case operated using this technique.
\end{abstract}

Keywords: Hydrocephalus; Glaucoma; Glaucoma drainage implants; Aqueous humor; Filtering surgery; Humans; Case reports

\section{RESUMO}

Calcula-se que em 2010 havia provavelmente 60,5 milhões de pessoas com glaucoma, com aumento previsto para 79,6 milhões em 2020; a cegueira bilateral por glaucoma era detectada em 8,4 milhões de pessoas, em 2010, e com aumento estimado para 11,2 milhões em 2020. Dispositivos especiais foram desenvolvidos para reduzir a pressão intraocular em pacientes com glaucoma refratário, chamados implantes de filtragem. A taxa de sucesso destes implantes é relativamente baixa, e sabe-se que elas continuam a diminuir ao longo do tempo. Para evitar as falhas produzidas pela cicatrização de tecido em torno dos implantes, foram feitas tentativas de drenagem do humor aquoso para diferentes locais, tais como o sistema venoso, saco lacrimal, os seios paranasais e fórnice conjuntival. Revendo o tratamento atual da hidrocefalia, uma técnica de derivação a partir da câmara anterior para o peritônio foi desenvolvida. A técnica cirúrgica desenvolvida é uma modificação da técnica atualmente utilizada por neurocirurgiões para o tratamento de hidrocefalia. Apresentamos o primeiro caso operado com esta técnica.

Descritores: Hidrocefalia; Glaucoma; Implantes para drenagem de glaucoma; Humor aquoso; Cirurgia filtrante; Humanos; Relatos de casos

\section{INTRODUCTION}

Glaucoma has a pathophysiology that is very similar to that of hydrocephalus. Both diseases are characterized by a disturbance of the production and absorption of liquids. The function of the cerebrospinal fluid (CSF) and the aqueous humor and their secretion and absorption are remarkably similar.

Hydrocephalus is defined as a disorder of the physiology of CSF(1). The prevalence of hydrocephalus in the population is $1-2 \%(2-3)$. Under normal conditions, CSF is produced by the choroid plexus ${ }^{(1)}$ at a rate of $500 \mathrm{ml} /$ day. It is reabsorbed gradually by a passive process into the venous system via the arachnoid villi(4) (arachnoid granulation).

In total, 70,000 cases of hydrocephalus are annually admitted to hospitals in the United States; of these, between 18 and 33,000 will be given CSF shunt devices ${ }^{(3)}$

Glaucoma is the leading cause of irreversible blindness worldwide ${ }^{(5-6)}$, with a prevalence of up to $4.74 \%{ }^{(7)}$. It is characterized by damage to the optic nerve fiber layer, resulting in progressive visual field disturbance. Intraocular pressure (IOP) is the most important risk factor for glaucoma; and currently, decreasing IOP is the only treatment option. Aqueous humor is produced by the ciliary body at a rate of 2.8-3.6 $\mathrm{ml}$ per day ${ }^{(8)}$, circulating from the posterior chamber to the anterior chamber, and it is absorbed into the venous system through the trabecular meshwork.
The latest development in the treatment of hydrocephalus has been the introduction of programmable valves ${ }^{(9)}$. These enable the desired pressure levels for each patient to be regulated in the doctor's office, avoiding the complications of under- or over-drainage of CSF, without the need for further surgery to change the devices ${ }^{(10)}$. Reviewing the current management of hydrocephalus, a system to shunt aqueous humor from the anterior chamber to the peritoneum has been developed. The surgical technique is a modification of the technique currently used by neurosurgeons to treat hydrocephalus, with the ventricular catheter being replaced by an ocular catheter.

\section{CASE REPORT}

The patient presented in this paper is enrolled in an ongoing research protocol at the Clínica de Ojos Maldonado Bas. The protocol has been approved by Oulton-Romagosa Institutional Health Research Ethics Committee, and respects the norms and standards enshrined in the Nuremberg Code, the Declaration of Helsinki, CIOMS/WHO Guidelines, the Universal Declaration on Bioethics and Human Rights (UNESCO), and other international and national instruments governing biomedical research.

A 40-year-old male patient with glaucoma presented to the clinic. He had a history of bilateral keratoplasty for keratoconus during
Submitted for publication: August 29, 2014

Accepted for publication: August 29, 2014

Anterior Segment Department, Clínica de Ojos Maldonado-Bas, Córdoba, Argentina.

2 Clínica de Ojos Maldonado-Bas, Córdoba, Argentina.

3 General Surgery Department, Hospital Municipal de Urgencias of the city of Córdoba, Córdoba,

Argentina.

${ }^{4}$ Department of Neurosurgery, Sanatorio Allende, Córdoba, Argentina.

${ }^{5}$ General Surgery Department, Hospital Misericordia Nuevo Siglo, Córdoba, Argentina.
Funding: No specific financial support was available for this study.

Disclosure of potential conflicts of interest: None of the authors have any potential conflicts of interest to disclose.

Corresponding author: Ana Maldonado-Junyent. Clínica de Ojos Maldonado-Bas - Achával Rodriguez 544 - Córdoba 5014 - Argentina - E-mail: anamjunyent@yahoo.com

Approved by the following research ethics committee: Approval №:013, CIEIS:OULTON-ROMAGOSA 
adolescence. After the corneal surgery he had developed bilateral glaucoma. He had undergone cataract surgery and 2 filtering surgeries in the right eye (OD) and filtering surgery in the left eye (OS). The visual acuity was no light perception in the OD and 4/10 in the OS. Slit-lamp examination of the OD showed keratoplasty with epithelial edema, a non-reactive dilated pupil with sector iridectomy, capsular pseudoexfoliation, pseudophakia, upper scleral thinning, and 2 nonfunctioning filtering blebs. IOP was $50 \mathrm{mmHg}$. Slit-lamp examination of the OS showed keratoplasty, permeable iridectomy, a transparent lens, and a functioning filtering bleb. IOP was $11 \mathrm{mmHg}$.

An aqueous humor shunt to the peritoneum was performed in the OD. A hydrocephalus valve (Medtronic PS Medical ${ }^{\oplus}$ Strata ${ }^{\circledR}$ NSC) was used, regulated at level 2.5 (to operate at pressures between 14 and $16 \mathrm{mmHg}$ ).

\section{SURGICAL TECHNIQUE}

The surgical procedure begins with the formation of a fornix-based conjunctival flap. The conjunctiva is lifted and its rear face is incised, making an opening of sufficient size to allow a surgical guidewire to pass with a silicone tube mounted on it. An incision is made in the retroauricular region of the scalp (Figure $1 \mathrm{~A}$ ), and the ocular catheter mounted on the surgical guidewire is passed from the opening of the rear face of the conjunctiva to the scalp incision (Figure 1B). A tunneler is passed from the scalp incision to the periumbilical region (Figure 1C), and an opening is made in the skin and the peritoneum in this region. The hydrocephalus valve is positioned and the ocular and peritoneal catheters are assembled with the hydrocephalus valve (Figure 2A). Next, puncture of the anterior chamber of the eye is performed, and the ocular catheter is inserted. A chamber maintainer is placed (Figure 2B) and connected to a bottle of balanced saline solution to test the permeability of the system (Figure $2 \mathrm{C}$ ). The peritoneal catheter is then introduced. All surgical wounds are closed.

\section{RESULTS}

For the first twenty days postoperatively, the IOP was constant at $15 \mathrm{mmHg}$. The anterior chamber had good depth at all follow-up examinations over this period. The keratoplasty became edematous during the first 72 hours, but this resolved with topical medication (prednisolone acetate).

To assess the precision with which these implants regulate pressure, during follow-up at week 4 the valve was adjusted to level 2.0 (to operate at pressures between 10 and $12 \mathrm{mmHg}$ ) and IOP immediately decreased to $11 \mathrm{mmHg}$ (Figures $3 \mathrm{~A}-\mathrm{C}$ ). During the third postoperative month, the valve was regulated back to level 2.5. IOP increased to $15 \mathrm{mmHg}$ over the following 24 hours.

On slit-lamp examination, and in the tomographic and radiological investigations in the fourth week after surgery, the catheters and valve were confirmed to be well located. (Figures 4 A-C).

Although the follow-up period of this patient is not yet significant to assess the efficacy of the surgery, this is the first report in the
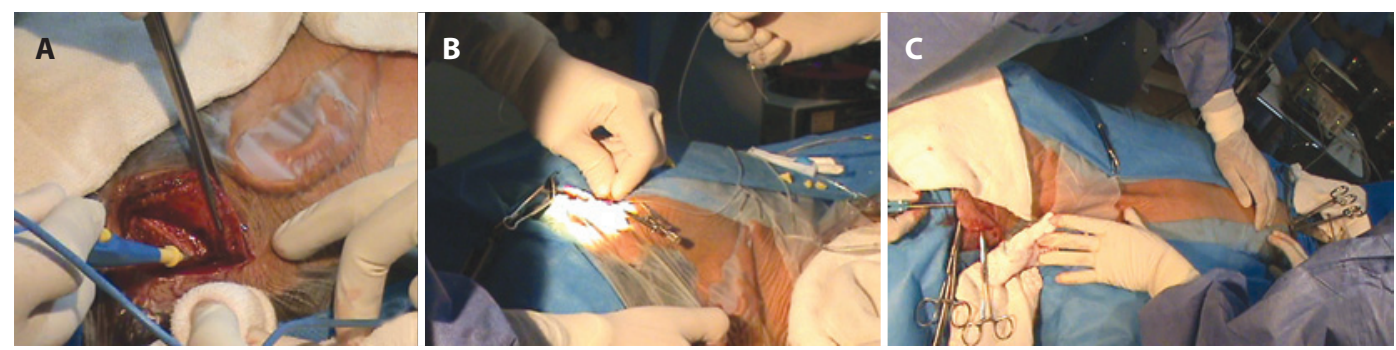

Figure 1. A) Scalp incision. B) The ocular catheter is passed into the scalp incision. C) The tunneler is passed from the scalp incision to the periumbilical region.
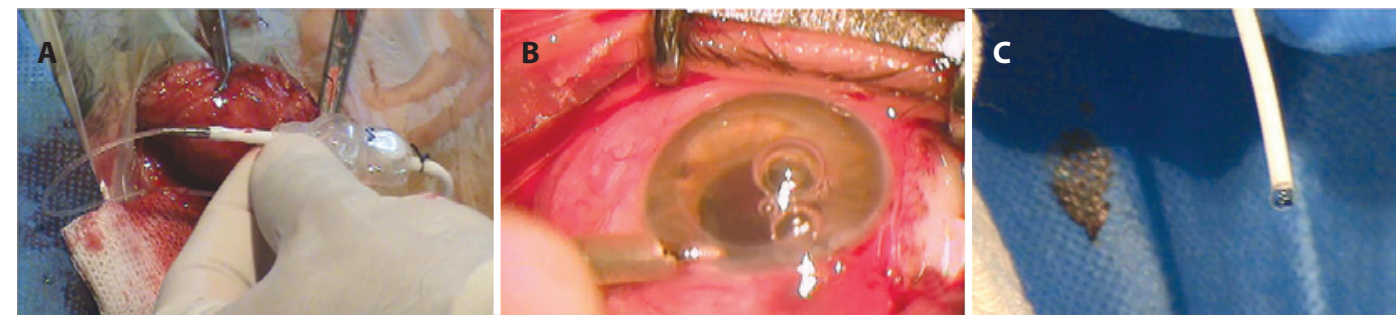

Figure 2. A) The ocular and peritoneal catheters are assembled with the hydrocephalus valve. B) Placing a chamber maintainer. C) Testing the permeability of the system.
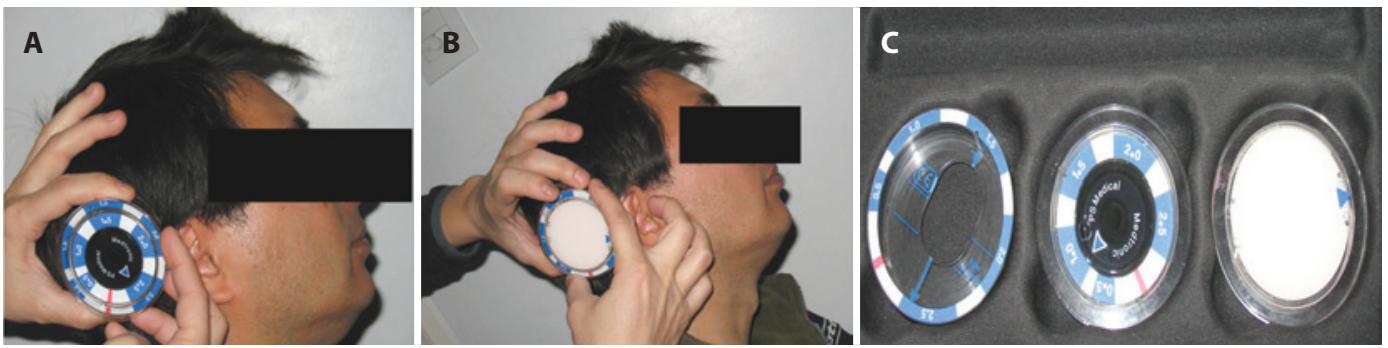

Figure 3. A) Checking the performance level of the device. B) Programming the device to level 2.0. C) Medtronic tools to adjust pressures. 

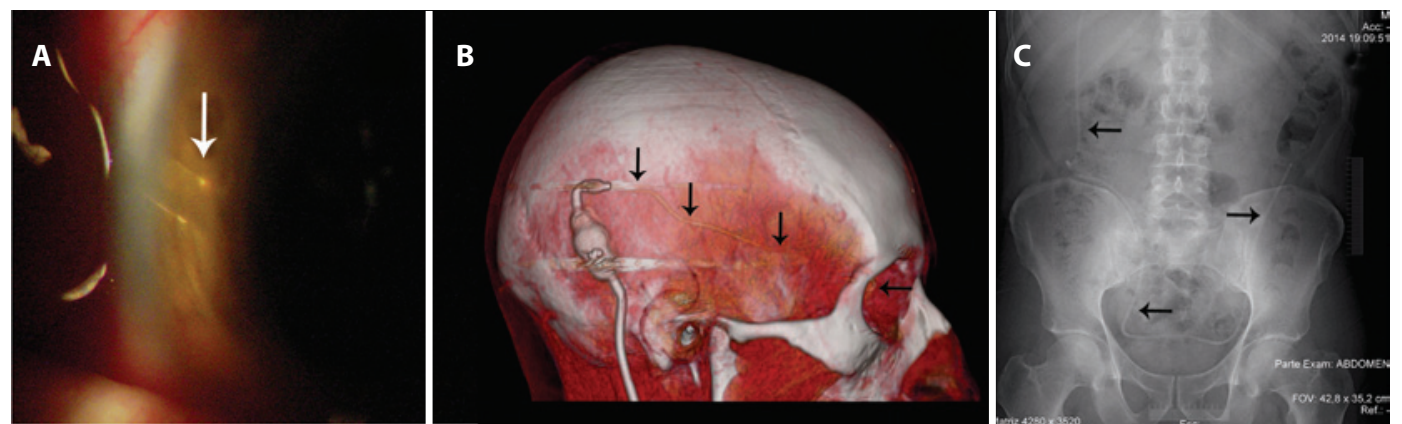

Figure 4. A) Slit-lamp examination showing the ocular catheter in position. B) Tomographic view showing the route of the ocular catheter (black arrows). C) Radiological view showing the peritoneal catheter in position (black arrows).

literature of this type of shunt. Filtering aqueous humor outside the orbital cavity, thus avoiding the main reason for failure of filtering surgery, and regulating IOP in the clinic during the postoperative period without patient re-intervention, are the main focus of this research.

More studies are needed in the future to evaluate the effectiveness of this type of shunt, and to continue adapting the remarkable technological advances in implants for hydrocephalus for use in ophthalmology. A multidisciplinary approach has enabled us to successfully develop this oculo-peritoneal shunt technique.

\section{ACKNOWLEDGEMENTS}

We wish to thank Moisés Dib MD, Enrique Bepmale, Alberto Siri MD, Fernando Nolé MD, Sandra Aban, Julio Carranza, Diego Maldonado-Junyent, Ana Junyent, Joss Heywood, and Héctor Tori.

\section{REFERENCES}

1. Garton HJL, Piatt JH Jr. Hydrocephalus. Pediatr Clin North Am. 2004;51(2):305-25.
2. Greenberg M. Handbook of Neurosurgery. $6^{\text {th }}$ ed. New York: Thieme Medical; 2006.

3. Bondurant $C P$, Jimenez DF. Epidemiology of cerebrospinal fluid shunting. Pediatr Neurosurg. 1995;23(5):254-8; discussion 259.

4. Albeck MJ, Borgesen SE, Gjerris F, Schmidt JF, Sorensen PS. Intracranial pressure and cerebrospinal fluid outflow conductance in healthy subjects. J Neurosurg. 1991; 74(4):597-600.

5. ResnikoffS, Pascolini D, Etya'ale D, Kocur I, Pararajasegaram R, Pokharel GP, et al. Global data on visual impairment in the year 2002. Bull World Health Organ. 2004;82(11):844-51.

6. Quigley HA, Broman AT. The number of people with glaucoma worldwide in 2010 and 2020. Br J Ophthalmol. 2006;90(3):262-7. Comment in: Br J Ophthalmol. 2006; 90(3):253-4.

7. Varma R, Ying-Lai M, Francis BA, Nquyen BB, Deneen J, Wilson MR, Azen SP; Los Angeles Latino Eye Study. Prevalence of open-angle glaucoma and ocular hypertension in Latinos: the Los Angeles Latino Eye Study. Ophthalmology. 2004;111(8):1439-48. Comment in: Ophthalmology. 2005;112(4):733; author reply 733-4.

8. Virno M, Taverniti L, De Gregorio F, Sedran L, Longo F. Increase in aqueous humor production following D1 receptors activation by means of ibopamine. Int Ophthalmol. 1997; 20(1-3):141-6.

9. Lollis SS, Mamourian AC, Vaccaro TJ, Duhaime AC. Programmable CSF shunt valves: radiographic identification and interpretation. AJNR Am J Neuroradiol. 2010;31(7):1343-6.

10. Watt S, Agerlin N, Romner B. Initial experience with the Codman Certas adjustable valve in the management of patients with hydrocephalus. Fluids Barriers CNS. 2012;9(1):21. 